\title{
Battle with Covid-19: the best recommendations for business professionals
}

Dinusha Dissanayake

Research scholar, Democratic Socialist Republic of Sri Lanka dinusha.d.dissanayake026@gmail.com

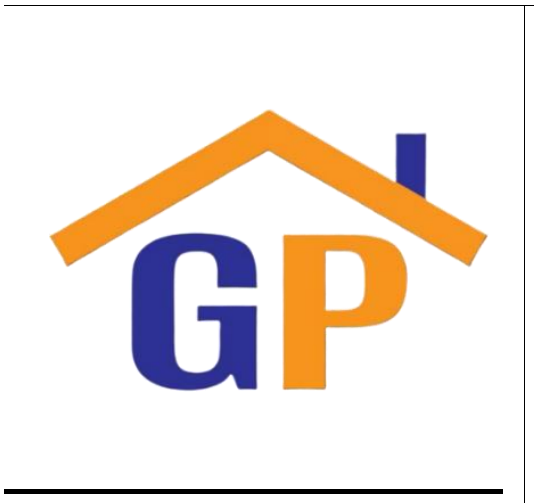

Article History

Received on 1 December 2020 Revised on 26 December 2020 Accepted on 5 January 2021

\begin{abstract}
Purpose: Workforce healthiness is presently considering the cutting-edge duty in any organization today. The motive of this effort is to provide the best recommendations for business professionals for the survival of their business.
\end{abstract}

Research methodology: The study was inductive and qualitative which conducted a methodical critique of literature as desk research. Pieces of writing in 2019 and 2020 have been reviewed. The content analysis is used as the analysis technique.

Results: The researcher recognized workforce protection, business continuity, financial crisis management, contingency planning, and review as five themes associated with the core recommendations for business professionals throughout the corona rampant.

Limitations: the secondary data and content analysis may cause subjective limitations to the study.

Contribution: Throughout the study, business professionals can review core practices that can adapt in the enterprise under the Coronavirus. Thus, they can use research findings for strategy formulation in the future.

Keywords: Covid-19, Recommendations, Business professionals

How to cite: Dissanayake, Dinusha. (2021). Battle with Covid-19: the best recommendations for business professionals. Annals of Human Resource Management Research, 1(1), 1-14.

\section{Introduction}

Covid-19 becomes the grand challenge to corporations today, generating a series of issues to the business environment across the globe. Once Charles Darwin quotes that beings who are adjustable to change must survive in the universe, neither intelligent once nor strongest once. This quote is suitable for the present scenario as well. Crises are not new to the universal context but important to effectively manage those crises with the minimum harm to society. The entire world is now facing an unrivalled catastrophe called Covid-19 which CO for corona, VI indicates virus and D remains for the disease. This Coronavirus causes several illnesses of human beings reasoning to fever, croak, breathing problems, heart attacks, kidney failures, and several unknown tenement failures that lead to the person's death. The scary story is still; there was no medicine or treatment for Covid-19.

The foremost human case of Coronavirus was detected in the municipality of Wuhan in China in December last year (2019). The subject experts rename this personage virus as a novel coronavirus (SARS-COV-2). The report of (World Health Organization, 2020) quoted that this virus remains with us for a longer period, people must adapt to the new normal living conditions in the future. At present Coronavirus spread across the cosmos like cancer. Thus, the (World Health Organization, 2020) further highlighted this virus directly transmitted to people when the virus drops reach their hands, nose, eyes, or mouth. To overcome these exposure medical experts recommend keeping a one-meter distance between two persons in public places. Thus, the most dangerous thing is there are no vaccines or drugs for corona disease. However, Humans are naturally interacting with each other. Employees are kind of human beings to interrelate with one another for industry requirements. 
Moreover, persuade background employers to protect their workers from the virus intention to the sustainability of the business in the future period.

Currently, Sri Lanka found 12,570 corona patients, and 29 of total deaths happen at the date of 6/11/2020 confirmed by the Epidemiology Unit, Ministry of Health Sri Lanka. When medical authorities identify an employee as a corona patient, the entire factory or enterprise should lock down. The duration must be a minimum of two weeks or unknown. It may cause huge losses to the company in the form of loss of sales, production, and supply channels, etc. Moreover, the incidental aftermath of the Coronavirus is greater than the direct effect. Thus, the prevalent is moreover similar to the iceberg in which the invisible effect is greater than the visible effect in any context over the globe. At present this virus affects the entire routine works and changes the normal life pattern of the Sri Lankans. At present all the citizens in the society have to play a critical frontline role to control this pandemic. Hence, Sri Lankan companies now seek a novelty direction to protect their employees and continue the business simultaneously. This combined task conceivably a critical challenge to the corporations during this corona period.

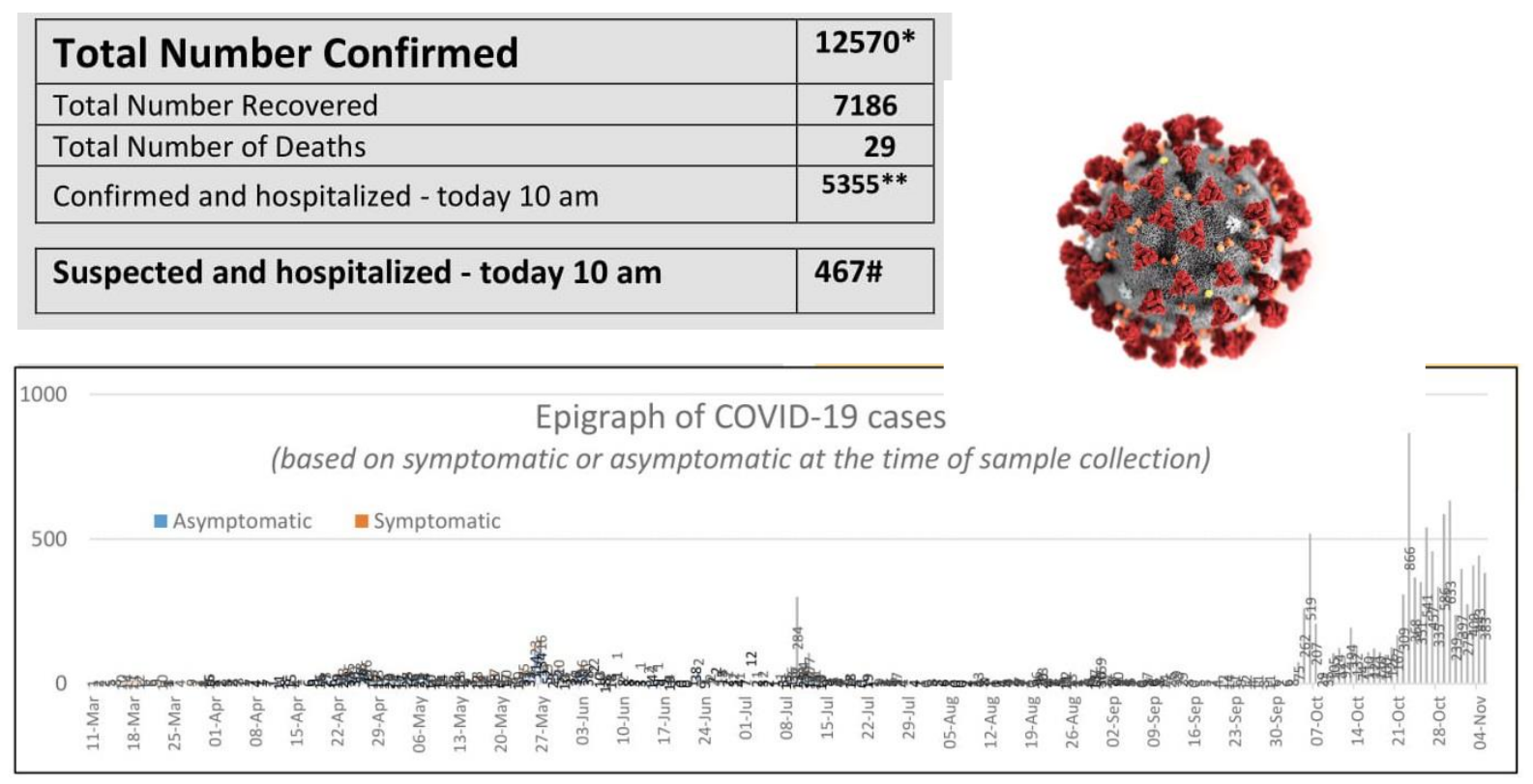

Figure 1: Situation report date of 6/11/2020

Source: (Epidemiology Unite, 2020, p.1).

Figure 1 illustrates the red notice of the critical situation in the area up to now. The country is now on the doorstep of a community spread about the above statistical report. If that happens nobody can predict what will happen to the country in the future. Moreover, presently company owners, managers, employees, and the entire society have a leading portrayal in controlling the virus within the country. In a corporate scenario, personal managers have a frontline function to protect their workforce from the invisible virus called Covid-19. Instead, corporate people have a prime duty to assure the staff's industry well-being in the current context. Organizational leaders must draw up and appliance new strategies to their current work domain to face the virus effectively. This examination bid to explain the best managerial practices that can successfully implement in the corona pandemic. Because of corona locus in the countryside researchers are curious to search what are the best practices and recommendations that can adapt to the organization to combat Covid-19.

Organizations across the world presently confronting the challenge of survival. At present managers require suggestions and best practices for business continuity. According to (Opatha P. J., 2020) Sri Lankan organizations considered more about employee well-being and health after the covid-19. Furthermore, (Wunderlich \& Lokke, 2020) mentioned that Denmark organizations focus more on business continuity and workforce protection during the pandemic. Managing firm finance and costs 
become a critical challenge during the virus situation in the UK. Firms are now seeking to manage costs. (Mckinsey \& Company, 2020). A contingency plan is important to face the crisis at present and in the future. (Accenture, 2020). Finally, (Nangia \& Mohsin, 2020) highlighted the importance of having the best managerial practices and business professionals' recommendations during the pandemic. Because of these explanations and the explorations researcher curious to find the best recommendations for business professionals during the pandemic, which motivated to construct the study's research objective. Thus, the study explains the key managerial practices that can adopt in the duration of the Coronavirus.

Now corporate change is compulsory to face the Covid-19 effectively plus build up the business industry again. At the movement, this virus pandemic creates several adverse effects on the Sri Lankan economy. Corporate entities and employees face a loss of jobs, reducing income, layoffs, pressure on debts, solvency problems, etc. The companies' HR departments now face the objection of employee retention due to the Covid-19 pandemic. (Elsafty \& Ragheb, 2020). Organizations require competent people to uplift the business again. Business leaders exhibit a great effort to keep worker morale. Employees are the heart of any organization. Without sound laborers, organizations cannot accomplish their targets on time and center long-standing time success. Workforce Safety and health are now considering the frontline function in any company. As per the quote of (Elsafty \& Ragheb, 2020) employee retention is now a challenge to the business entities by reasoning to Coronavirus. During the virus pandemic, the virtual teams and the software providers introduce new online flat foams to society for their regular routings. The previous studies show that competent archons always find an innovative way to conduct their business during crises. In the corona epidemic, we experienced some leaders take the optimum benefit to their business in the isolation period, which generates the business's right opportunity. Correspondingly, to overcome the detrimental ramification of the Covid-19 people now start to think differently, which leads to adjusting the new normal situation. Moreover, the researcher intends to explore the core recommendations that can adopt throughout the virus epidemic based on recognizing themes of empirical written works. Furthermore, a contemporary inquest's research problem is what are the best recommendations for Business professionals during the pandemic? And the research objective of the inquiry is to provide the best recommendations for business professionals to battle with Covid-19.

Citizens can move to a new future through the new normal circumstance. Occupational health and safety have become the dominant HR function in the past few decades which ensures a secure working atmosphere for employees. Human capital experts are liable for protecting their employees in the corporate context. According to (Dissanayake, 2019) mentioned the proper practice of health and safety reasons for productivity enhancement. Further, mentioned that investment in health and safety functions generates future benefits for the company. Protecting staff from the Coronavirus is the main duty of corporate administrators in the current scenario across the universe. Commensurate with the above context this paper explains the core recommendations for business professionals that can adapt in the abode under the Coronavirus based on recognizing themes of the literature survey. In a nutshell, now firms need situation-based decisions to battle with the virus because the future cannot forecast. Creative and innovative decisions always achieve outstanding results. In this corona, situation organizations require more innovative and creative decisions to minimize the injurious results of Covid-19.

Hence, some employees in the companies are having greater risk and reveal to the virus. Health sector workers, customer care officers, banking officers, security officers, post officers, are some of them who fall into the first respondent category. Conforming to the wording of the (Opatha H. , 2020) army and police officers, temporarand casual workers are more affected by the virus. He also mentioned that private-sector employees are being at more risk than government workers in the Sri Lankan scenario. As per the (Opatha H. , 2020) managing humans at work defined as human capital management. Hence, here the word people refer to the workforce. Instead, business management demonstrates the effective utilization of resources in the organization. Thus, exceptionally in crises managers and corporate leaders positively influence the workforce behavior for going concerned with the business - flexible rules, policies, and regulations smooth the current business functions under 
Coronavirus. As the reason for the Coronavirus now it time to modify and moderate prevailing organizational policies, rules, and regulations for the amelioration and the well-being of employees. Health and sanctuary management becomes the outstanding function of corporate management under the Covid-19 at present. All the activities that implement to fend staff health and well-being refer to health and safety. (Opatha H. , 2020). Attributable to the prevailing corona pandemic majority of organizations recognize the value of managing their workers' healthiness, which becomes the priority. Moreover, at display commerce pioneers recognized the best practices embrace within emergency circumstances compared to the past since of Coronavirus.

\section{Literature review}

At the movement business leaders were faced with an unpredictable situation because of the Coronavirus. Covid-19 becomes the foremost crisis in the business world at present. As a result of the virus, affection survival is an ultimatum for several corporate entities across the world. The healthiness of the workers now becomes the superiority other than any. Therefore, business whitecollars have to play an outstanding role in this pandemic situation. HRM has now become a strategic function rather than documentation. However, this section comprehensively illustrates the researchers' previous contributions to align with the corporate impact of Covid-19. As (Sekaran \& Bougie, 2016) pointed out a critical literature survey is a process that involves the identification, evaluation, and documentation of secondary data relevant to the problem. Literature Review helps the analyzer to come up with an in-detailed overview and guidance to the study. Literature Review provides a rigorous background to the researcher to conduct the study with full confidence and engage working expertly. When discussing the inclusive and exclusive criteria of the work, For the intention of maintaining the quality, the researcher uses the following types of data sources, including textbooks, refereed and peer-reviewed journals, periodicals, conference proceedings, and reports cited in the online databases of Sage, Google scholar, Springer link, Science Direct, Wiley and Emerald concerning Human aid management, organizational context, and Covid-19 as the major topics. The time for those secondary data is from 2019 to 2020. In the preliminary inquest, initiate that there was a gap that exists in previous studies. There was a lack of studies related to the business professional's role under corona pandemic in local and global contexts. The Researcher tries to fill those gaps through this study by exploring the core business practices that can be adopted in enterprises under the Covid-19 crisis. Empirical gap refers to the limitations of the existing work, the theory, or the phenomenon. After the documentary explores, the best of the researcher's knowledge, there were very few studies and theories fall in the business context and Covid-19. The theoretical gap of the study pointed out the theory falls short in the existing scenario. According to this study, a theoretical gap existed. Further empirical work is needed in business management and Covid-19 because there is no accepted theory built to practice business management during the corona pandemic successfully. The performance gap explains the variance between the current situation and the expected situation. When analyzing the local area's corporate practices, there were no acceptable practices relating to the business practices that can adapt in the workplace under the Covid-19 crisis. There were no accepted laws, rules, regulations, and standards for corona-related business management. The contextual gap arises when the problem does not address in the relevant context which there were very few studies conducted in local relation to Covid-19 to date. This study is one of the mainframe studies conducted to explore the core recommendations that can adapt in the workplace under the Covid-19 crisis. Finally, considering the time gap, there were very few studies in the global context and the local context relevant to the best corporate practices and the Covid-19 from 2019 to 2020.

When considering business functions, human resource management directly links with people. Occupational safety and health (OSH) are one of the key functions related to employees' physical, mental, and social well-being under HRM functions. The Manitoba Guidelines explains if there were ill persons in the office premises suffering from fever, cough, runny nose, etc. should go home and get treatments immediately. Immediate supervisors must closely observe the health conditions of the subordinates through the corona period. Covid-19 does have a considerable impact on the workforce. If one person is detected as a corona person, he or she can spread the virus across the organization at a quick second. Within the work premises or outside the work premises employees can infect Coronavirus directly or indirectly. There were no hierarchical gaps for the Coronavirus. Every level of 
representatives can be affected on the off chance that they are not mindful of the infection. The (World Health Organization, 2020) stated that Coronavirus transmission is highly effective in human beings compared with other animals.

Further, they mentioned their fundamental point is to secure the society from Covid-19 in alignment with a proper drug to treat patients, reduce community transmission, and minimize negative social impact and adverse economic effect in the countries. Thus, (Epidemiology Unite, 2020) reported confirmed people in corona in Sri Lanka was 12,570 to the date of 06/11/2020. According to (Elsafty \& Ragheb, 2020) managers should have the frontline obligation to secure workers from infection within the work environment. Further, mentioned that workplace guidelines and support are critical for employee retention in the corona pandemic. Conforming to (Dissanayake, 2019) stated organizational health \& safety practices directly impacted employee turnover. Thus, appropriate wellbeing and security policies add an extra advantage to the companies during the crisis. Sound health and safety situations always acquire sound working conditions for workers with minimum hazards, risks, and accidents.

According to (Ministry of Health and Indigenous Medical Services, Sri Lanka, 2020) reported that the first Sri Lankan case of Coronavirus in February of this year was a tourist woman from china. The Sri Lanka government has decided to lock down the country for three months in the current year to control the community transmission. However, compared with other countries Sri Lanka shows the improvement in the control corona epidemic in an effective way with achieving a minimum dead rate and high recovery rate of the patients. According to (Wimalaweera, 2020) the office of census and measurements (DCS) affirmed that the financially dynamic populace in Sri Lanka was 8.6 million in the 4th quarter of 2019 which $64.5 \%$ males and $35.5 \%$ females. Thus, $46 \%$ of the active population refers to service sector employees, $37 \%$ in the manufacturing sector, and $27 \%$ involved in the agricultural sector. As stated in (Carnevale \& Hatak, 2020) human asset administrators should support employees to adjust the new work system under the Covid-19.

Moreover, pointed out that workforce adjustment is a must to face the Coronavirus. The present situation has created several challenges for business experts to move the strategies to planning. Now, most of the firms are moving to remote operations. At present Covid-19 creates several challenges and opportunities for human capital professionals. According to (Torrentira, 2020) institutions and firms need the best management practices to battle the Coronavirus. The study concluded that collaborative effort requires battling the virus pandemic. Further, (Opatha P. J., 2020) stated employers have to play a front role to prevent the Coronavirus spread and keep the workplace safe. Furthermore, business professionals have a key portrayal to manage employee well-being while performing the day-to-day HR routing. Now industry professionals get ready to face the novel Coronavirus. Facility managers take necessary actions against the Coronavirus. This virus is a zoonotic virus that transmits animals and humans. (Infraspeak, 2020).

The (Center for Disease control and prevention, 2019) explains that strong organizational leadership requires managing the adverse impacts of Covid-19. Thus, Scenario planning is the main function of emergency management that organizations must prioritise a crisis like a corona (BMS Canada Risk Services Ltd, 2020). Within the think about (PWC, 2020) concluded that sectors of tourism, apparel, and textile, construction, and engineering, retail and consumer, banking and finance were severely influenced by the Coronavirus in the local context. The Report uncommonly highlights that the little and smaller-scale endeavors in those segments face monetary troubles in the future. Directors and corporate administrators have a basic obligation to secure workers from the invisible virus. Now companies ought to discover a better approach to working, new workforce design, and new workplace arrangements to battle with Coronavirus. Now firms move to the concept of work with COVID in the future (Deloitte Development LLC, 2020).

The quality and capabilities of the active workforce determined the productivity of the health system in a country. (Global Equity Initiative, 2004). Purposefulness, empathetic behavior, confidence, action-oriented, inspiring, resilient, awareness of mindsets, courageous are some leadership qualities in a crisis (Korn Ferry, 2020). Supervisors and firm managers must supply care and psychological 
support to their employees amid this infection widespread (Hammer, 2020). As per the guideline of (U.S. Department of Labor, 2020) mentioned employers should prepare a plan for the pandemic events in the future that generate advance to the employees in respective organizations. Further, a team of employees must train to lead pandemic situations and give employees competency training to face epidemic situations confidently in the future. Also, the report quoted that organizations need an additional guideline for Covid-19. Each and each layer of the organization must take after the rule to avoid Coronavirus within the work put. The truth is that now the entire world is ready to work with corona's new normal situation. The business professionals now adopt a new way of working, an effective communication channel to manage ongoing HR activities and provide support to the employees (Hellen, 2020). However, the Coronavirus may cause absenteeism, employee turnover, change in the traditional work pattern, loss of market share, and increased work pressure. Concurring to (Hrout, 2020) amid the crown widespread HR managers should do three main roles namely employee well-being and protection, business maintenance, and oversee the financial crisis. The (UNDP, 2020) mentioned this emergency may be a challenge for each nation and affect the entire global economy which it takes a minimum of ten years to recover the adverse effect. In understanding with (Support for Improvement in Governance and Management, 2020) pointed out managers should consider the following factors before adapting to the new normal epidemic namely number of staff, health risk in the firm, motivation, and energy, the number of remote workers. (Anseel, Antonakis, \& Bamberger, 2020) Mentioned Coronavirus caused for change in work style and shifted to remote work, unemployment, mental well-being, financial crisis, increase debt pressure and age, race, gender, status, personality, culture act as a moderating factor for the effect of Covid-19.

\section{Research methodology}

The research's methodological technique was inductive and qualitative, which conducted a systematic review of literature as desk research. The researcher reviewed 43 articles cited in the online databases of Sage, Google scholar, Springer link, Science Direct, Wiley, and Emerald with business and Covid19 as the topics. Documents published in 2019 and 2020 have been reviewed. The content analysis is used as the analysis technique. Information lessening, information show, and concluding were the three steps in data analysis. Data displayed by using a table.

\section{Results and discussions}

The inquiry's research objective is to provide the best recommendations for business professionals to battle with Covid-19. The researcher systematically evaluated the contents of the selected documents which enable the analysis of specific textual information. The researcher interpreted texts using coding, categorizing, and finally recognizing meaningful themes concerning the research objective.

According to the results, the researcher recognized five themes related to business professionals' key recommendations to battle with virus infection; namely, theme 1- workforce protection, theme 2business continuity, theme 3- financial crisis management, theme 4- contingency planning, theme 5review. Furthermore, the research problem demonstrates the best recommendations for business professionals to battle with the Covid-19 crisis? The analyst discovers the reply to over address based on recognized topics of writing audit. The following table summarizes the findings of the study. 
Table 1: Summary of the documentary review

\begin{tabular}{|c|c|c|}
\hline Author(s) & Origin & Recognized Themes \\
\hline (World Health Organization, 2020) & Geneva & \multirow{16}{*}{ Workforce protection } \\
\hline (Epidemiology Unite, 2020) & Sri Lanka & \\
\hline (Elsafty \& Ragheb, 2020) & Egypt & \\
\hline (Dissanayake, 2019) & Sri Lanka & \\
\hline (Carnevale \& Hatak, 2020) & US & \\
\hline (Torrentira, 2020) & Philippines & \\
\hline (Opatha, 2020) & Sri Lanka & \\
\hline (World Health Organization, 2020) & Geneva & \\
\hline (Democratic Socialist Republic of Sri Lanka, 2020) & Sri Lanka & \\
\hline (Infraspeak, 2020) & Brazil & \\
\hline (Center for Disease control and prevention, 2019) & USA & \\
\hline (Hammer, 2020) & Washington & \\
\hline (International Labour Organization, 2020) & Geneva & \\
\hline (Hamouche, 2020) & Dubai & \\
\hline (Nangia \& Mohsin, 2020) & India & \\
\hline (Hrout, 2020) & Jordan & \\
\hline
\end{tabular}

\begin{tabular}{|c|c|c|}
\hline Author(s) & Origin & Recognized Themes \\
\hline (Elsafty \& Ragheb, 2020) & Egypt & \multirow{12}{*}{ Business continuity } \\
\hline (Carnevale \& Hatak, 2020) & US & \\
\hline (Opatha, 2020) & Sri Lanka & \\
\hline (BMS Canada Risk Services Ltd, 2020) & Canada & \\
\hline (Deloitte Development LLC, 2020) & Canada & \\
\hline (Mayer brown, 2020) & New York & \\
\hline (SHRM, 2020) & Washington & \\
\hline (Wunderlich \& Lokke, 2020) & Denmark & \\
\hline (He \& Harris, 2020) & UK & \\
\hline (Spicer, 2020) & UK & \\
\hline (Hrout, 2020) & Jordan & \\
\hline (Eraso \& Garcés, 2020) & Spain & \\
\hline
\end{tabular}

\begin{tabular}{|c|c|c|}
\hline Author(s) & Origin & Recognized Themes \\
\hline (Opatha, 2020) & Sri Lanka & \multirow{9}{*}{ Financial crisis management } \\
\hline (PWC, 2020) & Sri Lanka & \\
\hline (SHRM, 2020) & Washington & \\
\hline (Watson, 2020) & Geneva & \\
\hline (Hrout, 2020) & Jordan & \\
\hline (Mckinsey \& Company, 2020) & UK & \\
\hline (University of Ruhuna, 2020) & Sri Lanka & \\
\hline (Wimalaweera, 2020) & Sri Lanka & \\
\hline (Opatha H. , 2020) & Sri Lanka & \\
\hline
\end{tabular}




\begin{tabular}{|c|c|c|}
\hline Author(s) & Origin & Recognized Themes \\
\hline (Dissanayake, 2019) & Sri Lanka & \multirow{8}{*}{ Contingency planning } \\
\hline (Carnevale \& Hatak, 2020) & US & \\
\hline (Torrentira, 2020) & Philippines & \\
\hline (Opatha, 2020) & Sri Lanka & \\
\hline (Center for Disease control and prevention, 2019) & USA & \\
\hline (U.S. Department of Labor, 2020) & Boston & \\
\hline (Accenture, 2020) & Dublin & \\
\hline (KPMG, 2020) & India & \\
\hline Author(s) & Origin & Recognized Themes \\
\hline (Carnevale \& Hatak, 2020) & US & \multirow{5}{*}{ Review } \\
\hline (Opatha, 2020) & Sri Lanka & \\
\hline $\begin{array}{l}\text { (Centers for Disease Control and Prevention (CDC), } \\
2020)\end{array}$ & USA & \\
\hline $\begin{array}{l}\text { (Ministry of Health and Indigenous Medical Services, } \\
\text { Sri Lanka. 2020) }\end{array}$ & Sri Lanka & \\
\hline (Mwita, 2020) & Tanzania & \\
\hline
\end{tabular}

Source-(compiled by the researcher, 2020)

\section{Theme 1- Workforce protection}

World Health Organization (WHO) is the main responsible body in the globe to produce technical guidance for workforce protection. The (World Health Organization, 2020) provides proper guidelines for workforce protection from the Coronavirus. They recommend maintaining the social distance in the work environment and strictly advice to follow the personal protective equipment plus apply the technical guidance for the workplace operations. However, the (Epidemiology Unite, 2020) quoted Sri Lankan citizens musbe profoundly concerned about the industry and workforce assurance since of a vast number of corona-positive individuals within the nation. (Elsafty \& Ragheb, 2020) pointed out Covid-19 created a lot of negative effects on the companies which mainly caused a loss of income, jobs, debt pressure, etc.

Moreover, in a recession time employees are the strategic tool to organizations for survival. Proper workforce protection strategies lead to retain competent employees in the organizations (Elsafty \& Ragheb, 2020). A proper health and safety policy always accomplishes workforce protection (Dissanayake, 2019). As per (Carnevale \& Hatak, 2020) work from domestic is the best solution for employee protection in the Coronavirus period. Personal protective equipment (PPE) provides the best security to the workforce in the corona period. The equipment includes surgical masks, face shields, goggles, gowns, shoe covers, sanitizers, etc. (Torrentira, 2020).

The (Opatha P. J., 2020) recommended using remote working, cloud techniques, and work from domestic strategies to secure staff from the Coronavirus. However, work alone might be a problem for employees in a virtual environment. Remote working requires routine and proper process plus worklife balance. Instead, organizations should maintain proper communication, preparation, and staff improvements for virtual work arrangements. In remote work arrangements, HR should play an outstanding role in performance management and appraisal. Too ought to consider ergonomics, physical and mental well-being of the workers whereas locks in remote assignments. In this sense, it is recommended to offer an online employee relation platform to solve worker matters and provide advice. The cleanliness of the workplace, washing hands, the distance between employees, avoiding provincial traveling, minimizing the events, proper communication between parties, and remote work arrangements are important highlights to overcome the corona in the office. (World Health 
Organization, 2020). The gazette of (Democratic Socialist Republic of Sri Lanka, 2020) ordered all citizens in the state about the minimum number of persons in public traveling, events, compulsory to wear a mask in the office premisesand keeps a social distance corona prevention practices within Sri Lanka. As (Infraspeak, 2020) mention, reducing concentration, diminishinstaff's physical closeness, cleaning, avoiding international trips, and keeping everyone informed were best practices adopted in brazil companies under the Coronavirus. The managers and supervisors have a critical role in safety assurance. Also, supervisors have liability to report the plant's health plightn the plant (Center for Disease control and prevention, 2019). Addresses to employees' basic needs, continuous communication, andotivation are some points to support the employees in the corona epidemic (Hammer, 2020). Organizations must be aware of the tools, technology, workload, compensation and rewards, communication, work time, report to work, data security, work-life balance, productivity, and government rules before allocating remote workers for employees. (International Labour Organization, 2020). Covid-19 creates a negative influence on the employees' mental health. Organizational and individual factors generate the moderating ramification to the psychic health of the workforce (Hamouche, 2020). As stated by (Nangia \& Mohsin, 2020) the primary objective of any organization is survival during the virus situation. Also, consider ensuring the safety and effectiveness of the laborers and maintain business continuity. Therefore, business experts must care for and enhance organizational efficiency and effectiveness through people. HR individuals particularly highlight this widespread period and all the partners recognize the esteem of the human asset experts at a show because of the widespread. Generally, employees are exposed to six hours per day on the premises of work. So it is the employers' main duty to provide adequate assurance to the employees in their plant premises. According to (Hrout, 2020) there were threprotection phases for employees in the working environment. Phase one includes creating awareness about the Coronavirus, information gathering, and recognizing the employees who have the basic manifestation of Coronavirus in the company. Phase two explains the necessary actions to forbid Coronavirus in the industrial premises. In this stage, employers can provide protective equipment to workers, temperature checking, sanitize the premises, minimize unwanted traveling, and maintain social distance. Level three refers to the modification of the current work system. Furthermore, suggest reducing paper works, reduce meetings and pieces of training, and encourage remote operations.

\section{Theme 2- Business continuity}

According to (Carnevale \& Hatak, 2020) training and development, recompense, career plan, and firm culture were the most important propositions for employee retention during the corona period. Further study quoted employee retention is critical for business continuity in a crisis. Implementing new workplace policies with limited human contact, electronic business operations, movingo virtual HR functioning, proper division of work, and flexible work conditions are reasons for business cohesion through Covid-19 (Elsafty \& Ragheb, 2020). Remote working conditions help to maintain the business constancy during the Coronavirus. Providing training to employees will enhance the efficacy of remote assignments. Work from home is an outstanding technique to maintain the worklife and family balance of the staff (Opatha P. J., 2020). Scenario planning, communication, and reputation are the most prevailing factors for the trade continuation throughout the crises (BMS Canada Risk Services Ltd, 2020). According to (Deloitte Development LLC, 2020) suggested three phases for business continuity in the corona pandemic. The first step is to respond to, which means deal with the current scenario. The second phase is recovered which explains learning and emerging. The third phase is thriving which refers to the adjustment to a new normal situation.

The (Mayer Brown, 2020) mentioned that keeping updated information, knowing the employees' locations, communication, a safe working environment, and flexibility are some best practices that companies can implement in a crisis. The research of (SHRM, 2020) pointed out 80\% of American businesses have formal or informal abidance plans. Under the survey (Wunderlich \& Lokke, 2020) found that top management support is needed for personnel managers to face the virus epidemic. The report also mentioned that business professionals should modify their current corporate functions suite to the prevailing situation. Especially functions like resourcing, training, and development, health and safety, employee relations, performance appraisals, etc. 
The (He \& Harris, 2020) pointed out Covid-19 situation offers several strengths and opportunities for the enterprises to grow in marketing and CSR. Thus, now most companies move towards social marketing and e-mail marketing as a result of virus infection. This generates merits to continue the business operations under the corona period. The corona epidemic is the most affected cultural shock in organizations today. Cultural change is requiring overcoming the adverse significance of Coronavirus. (Spicer, 2020). As stated by (Hrout, 2020) HR should help top management continue business operations by introducing work modifications. However, to gain the firm's objectives managers can implement remote work arrangements, encourage vacations, and provide E-based solutions. According to (Eraso \& Garcés, 2020) suggested companies should introduce telework as a solution to work continuity. Further, that study explains how teleworking can be used to face covid19. Thus, the study confirmed that teleworking can ensure employee safety and assure continuity of economic activities in the context.

\section{Theme 3- Financial crisis management}

Pay salaries and compensation are one of the extensive challenges confronted by the companies during Coronavirus. In the Sri Lankan scenario, most of the organizations shut down their business half of the prevailing year due to curfew and unstable conditions in the country. Still, companies cannot continue their business activities compared to the past. In the prevailing situation now firms cannot earn their regular profits as usual. So this may be the reason for increased debt pressure and financial crisis within the firms. According to the pay cuts and layoffs, it can be adoptedo minimize the financial crisis (Opatha P. J., 2020). HR managers have an outstanding part in pay management and maintain healthy industrial relations in the corona crisis. As per the outbreak report of (PWC, 2020) mentioned that micro and medium sector businesses face financial bankruptcy in the future because of the corona pandemic. The research of (SHRM, 2020) confirmed that half of the small sector businesses cannot pay employee salaries under quarantine. Moreover, 58\% of small and medium organizations in America informed that they did not meet the quarantine's basic financial needs. Further, American companies forecast a 10\%-30\% loss under the quarantine period. Thus, the report specifically mentioned that $50 \%$ of American workers informed that their job cannot be done remotely.

The (Watson, 2020) pointed out it is crucial to balance the short-term and long-term cost in the term of virus infection. If not it leads to the solvency of the company. Thus, pay cuts, working capital management, layoffs, winding the constructions, entertainment expenses, and bonuses are valuable strategies that can be taken in the crisis era. The (Hrout, 2020) pointed out organizations should manage their cost especially people related to HR costs during the Covid-19. If not it will lead to a series of monetary problems in the future. Here, she suggested freezing new hires, modifying the existing pay and benefits system, managing the allowance scheme, postpones the promotions and salary increases, and pay cuts plus headcount reductions as cost management strategies. As belongs to the report of (Mckinsey \& Company, 2020) building trust, ensuring workforce well-being, building social capital are some best practices to overcome financial difficulties in the corona pandemic. The research of (University of Ruhuna, 2020) confirmed that $64 \%$ of households made a $7 \%$ loss of their income sources while 3\% of households lost their entire income within Sri Lanka. Further, the study mentioned that the Covid-19 pandemic affects the saving levels, expense pattern, and debt of Sri Lankans adversely.

Respecting the labor market survey of (Wimalaweera, 2020) recommended the following facts to overcome the financial burden in the short term. Especially, Retain employee with deducted salaries, pay the number of hours they work remotely if possible, continue the granting of loans to provide working capital, Allow for the employers to recover a portion of 'lost paid hours, According (Opatha H. , 2020) when high performing employee of the firm gotten to be contaminated by the Coronavirus it may be a high cost to the organization. For some time it takes considerable time to recover the damage and the loss. If death happens the cost cannot be countable. 


\section{Theme 4- Contingency planning}

According to (Dissanayake, 2019) reactions to emergencies are an intercept component in organizational health and safety practices. An emergency health and safety plan is needed to face future unexpected challenges in the era of Covid-19 (Carnevale \& Hatak, 2020). A contingency plan is required to combat Coronavirus. It is important to detect virus-affected people in the early stage. This might be the best practice of contingency planning (Torrentira, 2020). It is better ready for PCR (Polymerase Chain Reaction) tests when required as a component in an organizational contingency plan.

The report of (Center for Disease control and prevention, 2019) pointed out that supervisors are responsible for undertaking and implementing the Corona prevention plan in organizations in special sites. According to (U.S. Department of Labor, 2020) infectious disease preparedness and response plaare the best mechanism to face the Coronavirus in the future. This eventually plans to measure the level of risk and the action plan to address those risks. In (Accenture, 2020) corona presents a material threat to the entire world. According to their reports, $12 \%$ of the world's organizations have their planning arrangements to deal with the Coronavirus than winding up the business operations. Further, they recommend three actions to face covid-19 effectively which prevent, prepare, and predict. According to (KPMG, 2020) stated managers must reshape their regular routing in alignment with the new normal situation after the Covid-19. They strictly advise business professionals to prepare a contingency plan include compensation and employee welfare.

\section{Theme 5- Review}

The virus pandemic creates an unknown future risk to the society we are living in. The health experts forecasted that for a minimum three years period of time people must deal with the Covid- 19 . Forward-thinking, innovations, novelty strategies motivate people to live with corona. Worker alteration is a must to work with a corona in the future. (Carnevale \& Hatak, 2020). Continuing medical tests and proper employee relations processes can reduce corona stress in the organization. However, proper communication between managers and employees is one outstanding practice in the review process. Communicating upgraded information to the staff amid the Covid-19 is best. (Opatha P. J., 2020). The (Centers for Disease Control and Prevention (CDC), 2020) highlights improvement planning recognizes the strength areas, weakness, and further improvement plus corrective actions within the emergency circumstance. According to (Ministry of Health and Indigenous Medical Services, Sri Lanka, 2020) as a country, Sri Lanka has a continuous review plan to address the Coronavirus in the future period. The plan consisted of three-phase namely, preparedness, response, and recovery plan.

The idea of (Mwita, 2020) now people must change their traditional lifestyles and adjust to the new normal life. The virus's negative effect was critical, and corporate experts must review and change their old practices to new normal practices. In this virus pandemic, HRM becomes the core function in the business context that would have not been identified before. The empirical studies refer to covid19 found that the number of recruitments and selections gradually decreased because of Covid-19. Most physical training programs were cancelled and online training programs were implemented. Performance management is recognized as the most challengeable HR function during the virus pandemic. Being the prevailing situation most of the employees did not achieve their desired goals within the year. Work from a place of the resident was generating difficulties in monitoring the workforce. Moreover, work-life balance also becomes a core challenge in remote work arrangements. In the word of (Mwita, 2020) recommended adopting electronic HRM concerning minimum employee fatigue and interaction. Thus, the further study reviewed and modified current HR arrangements continuously as per the corona anticipation rules.

When considering the articles on present corporate practices in companies, according to the disclose of (Dissanayake, 2019), (Opatha P. J., 2020), (University of Ruhuna, 2020), (Wimalaweera, 2020), 
the blue-chip companies in Sri Lanka like Brandix, Unilever, Mass holdings, Chevron, highly concern about the employee protection, business continuity, cost, and finance management and contingency planning plus review as battling strategies against the Covid-19. As per (Opatha H. , 2020) the companies located in the zones of the Board of Investment (BOI) strictly follow the health rules and regulations relating to covid-19. When considering the international corporate practices relating to Covid-19 it seems that the majority of the companies have given their priority to protect the employees and then lock at the business continuity. (Accenture, 2020). Moreover, companies in the UK practice one-meter distance, wearing masks and sanitization as a battling strategy for Coronavirus. (Mckinsey \& Company, 2020) The study's findings can be taken not only in the present scenario but as a proactive measure for any kind of pandemic in the future. The five themes namely workforce protection, business continuity, financial crisis management, contingency planning, and review could be applied as a universal model for any crisis in the business context. Further, the above initiatives act as the best recommendations for business professionals during the pandemic at present and in future pandemics. In the future, it is necessary to form an organizational contingency plan and periodic review of that plan to face the crisis effectively. Those five themes (Figure 1) act as a universal model for pandemic situations in the future for business context.

\section{Conclusion}

The complete world is presently fractioning an unrivalled virus pandemic called Covid-19 which adversely affects human beings' lives across the world. Due to the virus pandemic, business professionals have a significant task to protect their employees. The article's research objective was to provide the best recommendations for business professionals to battle with Covid-19. The methodology of the research was inductive and qualitative. The researcher conducted a systematic review of literature cited in the online databases of Sage, Google scholar, Springer link, Science Direct, Wiley, and Emerald with business and Covid-19 as the topics. Articles published in 2019 and 2020 have been reviewed. The content analysis is used as the analysis technique. According to the findings, business administrators had the main five recommendations to battle with the Covid-19 epidemic namely, workforce protection, business continuity, financial crisis management, contingency planning, and review. These five factors become a principle for business professionals under the Coronavirus, which is important as the hand's five fingers. Finally, the study concludes that workforce protection; business continuity, financial crisis management, contingency planning, and review were the best-recommended practices that can adapt in the enterprises during the Covid-19 crisis as well as future pandemic situations. However, the researcher suggests revising the Factories Ordinance (No 19 of 1934), the Shop and Office Employment Act (No 19 of 1954), and other labour laws suit with the Covid-19 crisis in Sri Lanka.

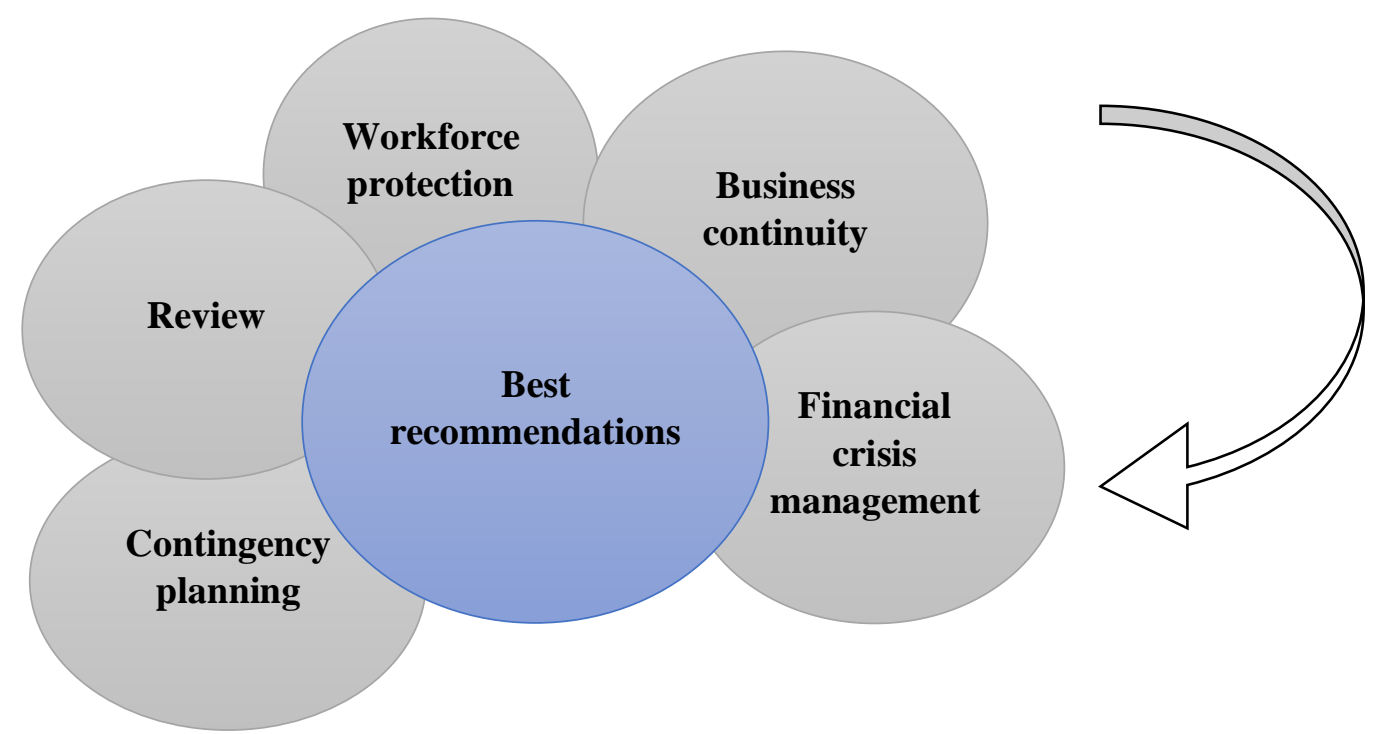

Figure 1: Best recommendations for business professionals to battle with Covid-19

Source - (compiled by the researcher, 2020) 


\section{Limitation and study forward}

This study uses only secondary data and conducted content analysis. This may cause some subjective conclusions. Thus, limited empirical studies were conducted that refer to the Coronavirus across the countries up to now. Further, the researcher suggests conducting a quantitative study or mixed study related to this topic in the future.

\section{Acknowledgment}

The author acknowledges the health sector workers, armed forces, police, and public health inspectors, media, and state intelligence services in Sri Lanka who battle with the Covid-19 crisis in the local context. Instead, the author thanks the admin and the reviewers of the annals of human resource management research (AHRMR) to create global value to this article.

\section{References}

Accenture. (2020). Continuity in Crisis. Dublin: Accenture global.

Anseel, F., Antonakis, J., \& Bamberger, P. A. (2020). COVID-19 and the Workplace: Implications, Issues, and Insights for Future Research and Action. COVID-19 and the Workplace, 2-43.

BMS Canada Risk Services Ltd. (2020). Crisis management during the covid-19 pandemic. Canada: BMS Canada Risk Services.

Carnevale, J., \& Hatak, I. (2020). Employee Adjustment and Well-Being in the Era of COVID-19: Implications for Human Resource Management. Journal of Business Research, 183-187.

Center for Disease control and prevention. (2019). Guidance for Business and employers. United states: Department of Health and human services.

Centers for Disease Control and Prevention (CDC). (2020). COVID-19 Vaccination Program. US: Department of health.

Deloitte Development LLC. (2020). Workforce strategies for a post-COVID-19 recovery. Canada: Deloitte.

Democratic Socialist Republic of Sri Lanka. (2020). The Gazette of the Democratic Socialist Republic of Sri Lanka. Colombo: Government of Sri Lanka.

Dissanayake, D. (2019). Impact of organizational health and safety practices on employee turnover intention. HRM Perspective, 1-13.

Elsafty, A., \& Ragheb, M. (2020). The Role of Human Resource Management Towards Employees Retention During Covid-19 Pandemic in Medical Supplies Sector - Egypt. Business and Management Studies, 50-59.

Epidemiology Unite. (2020). Corona virus (COVID-19) situational report - 6/11/2020. colombo: Ministry of Health.

Eraso, A. B., \& Garcés, A. E. (2020). Teleworking in the Context of the Covid-19 Crisis. Sustainability, 1-18.

Global Equity Initiative. (2004). Human Resources for Health: Overcoming the Crisis. Kotilainen: Harvard University.

Hammer, L. (2020). what supervisors/managers can do to support and respond to employees during the covid-19 epidemic. Washington: Oregon Helthy workforce centre.

Hamouche, S. (2020). COVID-19 and employees' mental health: stressors, moderators and agenda for organizational actions. Emerald Open Research, 2-15.

He, H., \& Harris, L. (2020). The Impact of Covid-19 Pandemic on Corporate Social Responsibility and Marketing Philosophy. Journal of Business Research, 1-28.

Hellen, C. (2020). The role of HR against the backdrop of COVID-19. ireland: Ibec consulting.

Hrout, R. (2020). Human Resources Role During Coronavirus Crises. HR and Organizational Behavior, 1-6.

Infraspeak. (2020). Dealing with Coronavirus (covid-19) as a facility manager. Brazil: Infraspeak global.

International Labour Organization. (2020). An employers' guide on working from home in response to the outbreak of COVID-19. Genève: ILO Bureau for Employers' Activities.

Korn Ferry. (2020). The covid-19 leadership guide. Los angeles: Korn Ferry consultants.

KPMG. (2020). Workforce, Workplace and HR reshaping. India: KPMG. 
Manitoba Guidlines. (2020). Covid-19- novel coronavirus. Canada: Manitoba.

Mayer brown. (2020). Managing HR Through COVID-19. New York: Mayer Brown publication.

Mckinsey \& Company. (2020). COVID-19 and the employee experience: How leaders can seize the moment. UK: Mckinsey \& Company publications.

Ministry of Health and Indigenous Medical Services, Sri Lanka. (2020). Sri Lanka Preparedness \& Response Plan COVID-19. Colombo: Ministry of Health Sri Lanka.

Mwita, K. (2020). Effects of corona virus pandemic (covid-19) on selected human resource management practices in tanzania. East African Journal of Social and Applied Sciences, 252259.

Nangia, M., \& Mohsin, F. (2020). Revisiting Talent Management Practices In A Pandemic Driven Vuca Environment - A Qualitative Investigation In The Indian It Industry. Journal of Critical Reviews, 937-942.

Opatha, H. (2020). The Coronavirus and The Employees: A Study from the Point of Human Resource Management. Sri Lankan Journal of Human Resource Management, 37-49.

Opatha, P. J. (2020). COVID-19 in Sri Lanka and Seven HRM Related Recommendations against COVID-19. Asian Journal of Social Sciences and Management Studies, 152-157.

PWC. (2020). COVID-19 Outbreak, Impact on Sri Lanka and Recommendations. Colombo: PWC Sri Lanka.

Sekaran, u., \& bougie, r. (2016). Research Methods for Business. United Kingdom: John Wiley \& Sons Ltd.

SHRM. (2020). Covid-19 research, implications for the american workforce. Washington: SHRM publications.

Spicer, A. (2020). Organizational Culture and COVID-19. Journal of Management science, 1-5.

Support for Improvement in Governance and Management. (2020). Human resource management in the context of Coronavirus (COVID-19). France: OECD.

Torrentira, M. (2020). Combating COVID-19 Pandemic: The Best Management Practices of A Designated Hospital in Southern Philippines. Journal of Business and Management Studies, $11-15$.

U.S. Department of Labor. (2020). Guidance on Preparing Workplaces for COVID-19. Boston: Department of Labor.

UNDP. (2020). Covid-19 and human development. Us: UNDP.

University of Ruhuna. (2020). The Economic Impact of the COVID-19 Pandemic in Sri Lanka. Matara: Faculty of Humanities and Social Sciences, University of Ruhuna.

Watson, W. T. (2020). Workforce Principles for the COVID-19 Pandemic Stakeholder Capitalism in a Time of Crisis. Geneva: World Economic Forum.

Wimalaweera, A. (2020). Covid 19 \& Beyond- The impact on the Labour Market of Sri Lanka. Sri Lanka: Department Of Labour, Sri Lanka.

World Health Organization. (2020). Coronavirus disease 2019 (COVID-19)-Situation Report - 94. Geneva: World Health Organization.

World Health Organization. (2020). Getting your workplace ready for COVID-19. Geneva: World Health Organization.

Wunderlich, M. F., \& Lokke, A. K. (2020). Human Resource Management Practices in Times of the COVID-19 Pandemic. Denmark: AARHUS University. 